Dhaka Univ. J. Sci. 61(1): 71-74, 2013 (January)

\title{
Accuracy Assessment of a Satellite Based Method for Solar Radiation Estimation
}

\author{
M. Shahjahan Ali ${ }^{1 *}$, H. Rahman ${ }^{2}$, S.K. Aditya ${ }^{3}$ and R. K. Mazumder ${ }^{3}$ \\ ${ }^{I}$ Department of Applied Physics, Electronics and Communication Engineering, Islamic University, \\ Kushtia-7003, Bangladesh \\ ${ }^{2}$ Bangladesh Space Research and Remote Sensing Organization (SPARRSO), Agargaon, Sher-e-Bangla Nagar, \\ Dhaka-1216, Bangladesh \\ ${ }^{3}$ Department of Applied Physics, Electronics and Communication Engineering, Dhaka University, Dhaka-1000, Bangladesh
}

Received on 05. 12. 2011. Accepted for Published on 12. 05. 2012

\begin{abstract}
In this study a simple statistical model has been used to estimate hourly solar global radiation over Bangladesh for two different time periods. Only the visible channel $(0.63 \mu \mathrm{m})$ data of NOAA-AVHRR digital images, obtained from Bangladesh Space Research and Remote Sensing Organization, has been processed to find the cloud index, a parameter which includes the horizontal extension of clouds and its optical thickness. Ground measured (pyranometer) data, obtained from Bangladesh Meteorological Department, has been used to obtain the total atmospheric transmission factor. One set of cloud index-atmospheric transmission factor data pairs has been used to find the regression coefficients using a statistical model. Once these coefficients are obtained these are then applied to the other set to calculate the ground irradiation.

Ground solar global irradiation for two places has been estimated for two months through application of this method. Accuracy of the method for calculating surface insolation has been checked in two ways. Reasonably good correlation between the measured and estimated irradiation has been observed for all cases. The root mean square error (RMSE) varies between $7.99 \%$ and $13.62 \%$ and mean bias error (MBE) from $-7.22 \%$ to $+9.54 \%$. The method can be used for calculation of hourly irradiation over areas in a tropical environment.
\end{abstract}

\section{Key Words: Solar Radiation, NOAA-AVHRR, RMSE, Bias error}

\section{Introduction}

The interaction of atmosphere and geo-sphere has significant influence on the Earth's climate system. Accurate knowledge of surface radiation budget is of particular importance as it constitutes the principal forcing variable which drives the energy exchange process. One way of getting detailed knowledge of the temporal and spatial variation of solar irradiance is by interpolating between ground measurement stations. But as the pixel sizes of the modern satellites are becoming smaller, it has been observed that satellite retrievals are more accurate than interpolating ground measurements. This study focuses on one component of the surface radiation budget, i.e., the downwelling solar surface irradiance. Many algorithms have been developed for its estimation from satellite data. In a review paper [1], Noia et al. described the best known methods developed using both the statistical and physical models from geostationary satellite data. Also there are some other methods developed from sun synchronous polar orbiter satellite data $[2,3]$.

\section{Operational Method}

The method used in this study is a statistical model. The basic idea of the model is that the amount of cloud covering over a given area statistically determines the global solar radiation received by that area. A ground based radiometer ( as for example a pyranometer) measures radiation with a fine time scale but over a particular geographical point, whereas satellite based radiometer measures cloudiness over a very large geographical area but having a poor time scale (one or two images in a day). According to Tarpley [4], averaging satellite data over a larger area is equivalent to averaging point measurements (pyranometer) over longer time periods. So the most crucial part for this type of models is to find the proper correlation between space based measurement and ground measurement.

In this study, remote sensing data from sun-synchronous NOAA KLM series of satellites, captured by Bangladesh Space Research and Remote Sensing Organization (SPARRSO), have been used to find the cloudiness. The full resolution $(1 \mathrm{~km})$ images of NOAA-17 satellite have been duly preprocessed. The preprocessing stages include- data collection and quality checking, selection of satellite radiometer channel, noise removal, geometric correction and image registration, radiometric calibration and conversion of $\mathrm{DN}$ values to physical parameters, sun angle effect and sun-earth distance effect correction, preparation of ground reflectance digital layer, preparation of cloud reflectance digital layer etc. These preprocessed images are then further processed for estimation of hourly solar irradiation on earth's surface. Only the visible channel data, bandwidth $0.58-0.68 \mu \mathrm{m}$, have been used in this work to infer the cloud properties. Ground measured pyranometer data, obtained from Bangladesh Meteorological Department (BMD), have been used to obtain the transmission factor of the atmosphere. Taking simultaneous measurements of ground

*corresponding author.E-Mail: jahanshah.iu@gmail.com 
based radiometer and satellite based sensor, model coefficients $(a, b)$ have been determined using a regression technique. The method for estimation of incident radiation used in the present study operates in three main steps. In the first step cloud cover index for each point on the satellite image is determined. In the second step model coefficients are derived using regression technique and these coefficients are used in the third step to calculate the irradiation on the earth's surface. Details of the procedure has been described in our previous study $[5,6]$.

\section{Result and Discussion}

Accuracy of the method in estimating global solar irradiation has been tested in two ways. In the first approach, monthly data-sets (satellite based cloud index and ground based atmospheric transmission factor) for each station have been divided into two groups. One set of the data has been used to find out the regression coefficients for the month for the particular station. These coefficients are then applied on the second data set of the same station to estimate irradiation at that station. The selection of data for a particular group has been made by random choice. The overall processing for one month at one station (in this case month April-May for station-Dhaka) has been shown in table-1(a) and 1(b). The performance of the method has been tested by calculating relative deviation, root mean square error (RMSE) and mean bias error (MBE) between the results obtained by means of satellite data and that provided by pyranometer. The same method has been followed to estimate irradiation for the rest of the cases i.e., station Dhaka, month February-March; station Rangamati, month April-May; station Rangamati, month February-March and the results have been summarized as shown in table-2. From the study, it is observed that the root mean square deviation between the hourly measured and model estimated irradiation for the study period varies between $7.99 \%$ and $13.62 \%$ and the bias varies between $+6.98 \%$ and $-4.62 \%$.

Table. 1(a). Dataset for finding regression coefficients of the month April-May for station Dhaka.

\begin{tabular}{|c|c|c|c|c|c|}
\hline $\begin{array}{c}\text { Date } \\
\text { (Time) }\end{array}$ & $\begin{array}{c}\text { Extraterrestrial } \\
\text { Irradiation }\end{array}$ & $\begin{array}{c}\text { Ground Measured } \\
\text { Hourly Irradiation }\end{array}$ & $\begin{array}{c}\text { Atmospheric } \\
\text { Transmittance } \\
\text { Factor }\end{array}$ & $\begin{array}{c}\text { Cloud Index from } \\
\text { Satellite Data }\end{array}$ & \multicolumn{2}{c|}{$\begin{array}{c}\text { Regression } \\
\text { Coefficients }\end{array}$} \\
\hline $\begin{array}{c}20 \text { April } \\
(10: 40)\end{array}$ & 1240.263 & 495 & 0.399109 & 0.675 & $\mathrm{a}$ \\
\hline $\begin{array}{c}21 \text { April } \\
(10: 15)\end{array}$ & 1192.876 & 720 & 0.603583 & 0.024 \\
\hline $\begin{array}{c}24 \text { April } \\
(10: 45)\end{array}$ & 1258.63 & 693 & 0.550599 & 0.042 \\
\hline $\begin{array}{c}26 \text { April } \\
(10: 00)\end{array}$ & 1163.437 & 697 & 0.599087 & 0.232 \\
\hline $\begin{array}{c}28 \text { April } \\
(11: 00)\end{array}$ & 1275.992 & 735 & 0.576022 & 0.463 \\
\hline $\begin{array}{c}30 \text { April } \\
(10: 10)\end{array}$ & 1195.095 & 600 & 0.502052 & 0.516 \\
\hline $\begin{array}{c}7 \text { May } \\
(10: 45)\end{array}$ & 1270.962 & 736 & 0.579089 & 0.19 \\
\hline $\begin{array}{c}9 \text { May } \\
(10: 45)\end{array}$ & 1263.228 & 270 & 0.213738 & 0.916 \\
\hline $\begin{array}{c}12 \text { May } \\
(10: 55)\end{array}$ & 1280.913 & 770 & 0.601134 & 0.028 \\
\hline $\begin{array}{c}16 \text { May } \\
(10: 40)\end{array}$ & 1262.291 & 776 & 0.614755 & 0.185 \\
\hline
\end{tabular}


Table. 1(b). Dataset for estimation of radiation of the month April-May for station Dhaka.

\begin{tabular}{|c|c|c|c|c|c|c|}
\hline \multirow{2}{*}{$\begin{array}{l}\text { Date } \\
\text { (Time) }\end{array}$} & \multirow{2}{*}{$\begin{array}{c}\text { Calculation of } \\
\text { Atmospheric } \\
\text { Transmittance } \\
\text { Factor Using } \\
\text { Coefficients form } \\
\text { table-1(a) }\end{array}$} & \multirow{2}{*}{$\begin{array}{l}\text { Estimation of } \\
\text { Hourly } \\
\text { Irradiation }\end{array}$} & \multirow{2}{*}{$\begin{array}{l}\text { Ground } \\
\text { Measured } \\
\text { Hourly } \\
\text { Irradiation }\end{array}$} & \multicolumn{3}{|c|}{ Calculation of Errors } \\
\hline & & & & $\begin{array}{l}\text { Relative } \\
\text { Deviation }\end{array}$ & $\begin{array}{l}\text { Root Mean } \\
\text { Square Error } \\
\text { (RMSE) }\end{array}$ & $\begin{array}{c}\text { Mean Bias } \\
\text { Error } \\
(\mathrm{MBE})\end{array}$ \\
\hline $\begin{array}{l}\text { 19 April } \\
(11: 00)\end{array}$ & 0.60547 & 772.8961 & 750 & 0.0305 & \multirow{5}{*}{0.136} & \multirow{5}{*}{0.069} \\
\hline $\begin{array}{l}25 \text { April } \\
(10: 20)\end{array}$ & 0.60547 & 735.744 & 790 & -0.0687 & & \\
\hline $\begin{array}{l}4 \text { May } \\
(10: 10)\end{array}$ & 0.277 & 330.8228 & 280 & 0.1815 & & \\
\hline $\begin{array}{l}\text { 11 May } \\
(11: 00)\end{array}$ & 0.57978 & 745.0095 & 605 & 0.2314 & & \\
\hline $\begin{array}{l}\text { 18 May } \\
(10: 00)\end{array}$ & 0.47775 & 557.1474 & 572 & -0.026 & & \\
\hline
\end{tabular}

Table. 2. Estimation Errors in the form of RMSE and MBE (first approach)

\begin{tabular}{|c|c|c|c|}
\hline Month & Station & $\begin{array}{c}\text { Root mean } \\
\text { square error } \\
\text { (RMSE) } \%\end{array}$ & $\begin{array}{c}\text { Mean bias } \\
\text { error (MBE) \% }\end{array}$ \\
\hline $\begin{array}{c}\text { April-May, } \\
\text { 2005 }\end{array}$ & Dhaka & 13.62 & 6.98 \\
\hline $\begin{array}{c}\text { April-May, } \\
\text { 2005 }\end{array}$ & Rangamati & 8.13 & -4.62 \\
\hline $\begin{array}{c}\text { February- } \\
\text { March, 2005 }\end{array}$ & Dhaka & 7.99 & -2.17 \\
\hline $\begin{array}{c}\text { February- } \\
\text { March, 2005 }\end{array}$ & Rangamati & 11.65 & 4.22 \\
\hline
\end{tabular}

In the second approach, regression coefficients ( $a$ and $b$ ) for each station have been determined using all the data-pairs of the respective stations for a month. These coefficients of one station are then applied on the other station to estimate irradiation for the later station for same month. The accuracy of the model in this case has been shown in table3. Fig 2. presents the scatter plots between the ground measured and model estimated irradiation for four cases. In this approach rms error varies from $11.46 \%$ to $13.41 \%$ and bias from $-7.22 \%$ to $+9.54 \%$.

Biases for the two stations show an opposing trend for the two time periods. In the first approach, when the training and estimation station is same, station-Dhaka shows positive bias (over estimation) in April-May and negative bias (under estimation) in February-March. On the other hand, stationRangamati shows positive bias in February-March and negative bias in April-May. In the second approach, when the training and estimation stations are different, stationDhaka shows positive bias in February-March period and negative bias in April-May period whereas stationRangamati shows positive and negative bias in April-May and February-March periods respectively.

Tarpley developed a regression technique to estimate daily insolation using GOES satellite data [4]. The standard error in this method was within $10 \%$ of the average daily measurement.

Table. 3. Evaluation of the method by calculation of errors taking coefficient from other station ( $2^{\text {nd }}$ approach)

\begin{tabular}{|c|c|c|c|c|}
\hline Month & $\begin{array}{c}\text { Estimation } \\
\text { Station }\end{array}$ & $\begin{array}{c}\text { Using Coefficient From } \\
\text { Station }\end{array}$ & $\begin{array}{c}\text { RMSE } \\
(\%)\end{array}$ & $\begin{array}{c}\text { MBE } \\
(\%)\end{array}$ \\
\hline $\begin{array}{c}\text { February- } \\
\text { March }\end{array}$ & Dhaka & $\begin{array}{c}\text { Rangamati } \\
\mathrm{a}=-0.3176, \mathrm{~b}=0.6862, \\
\mathrm{R}^{2}=0.6822\end{array}$ & 13.41 & 9.54 \\
$\begin{array}{c}\text { February- } \\
\text { March }\end{array}$ & Rangamati & $\begin{array}{c}\text { Dhaka } \\
\mathrm{a}=-0.3927, \mathrm{~b}=0.6494, \\
\mathrm{R}^{2}=0.9181\end{array}$ & 12.04 & -7.22 \\
\hline April-May & Dhaka & $\begin{array}{c}\text { Rangamati } \\
\mathrm{a}=-0.4909, \mathrm{~b}=0.6554, \\
\mathrm{R}^{2}=0.69\end{array}$ & 13.49 & -3.95 \\
\hline April-May & Rangamati & $\begin{array}{c}\text { Dhaka } \\
\mathrm{a}=-0.3775, \mathrm{~b}=0.6401, \\
\mathrm{R}^{2}=0.8085\end{array}$ & 11.46 & 1.19 \\
& & & \\
\hline
\end{tabular}

Cano et al. developed an empirical method using METEOSAT satellite for application in Europe for the prediction of hourly global radiation [7]. The average rms error (hourly measurement), for two different approaches, in this study were $117 \mathrm{Whm}^{-2}$ and $67 \mathrm{Whm}^{-2}$ respectively. 

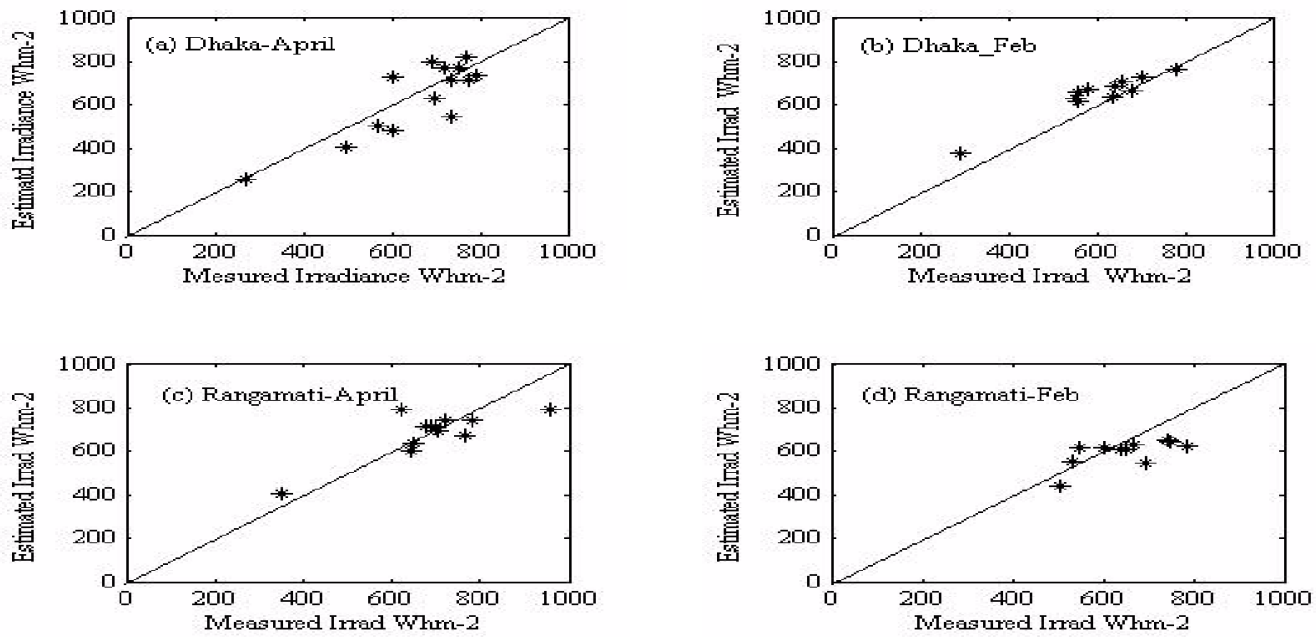

Fig. 2. Measured versus estimated hourly irradiation for the two time periods for two stations. (a) Station- Dhaka, Month: April-May (b) Station- Dhaka, Month: February-March (c) Station-Rangamati, Month: April-May and (d) Station-Rangamati, Month: February-March. The diagonal line indicates the perfect agreement between the measured and estimated values.

Islam and Excell developed a bispectral statistical method for Thailand using data from polar orbiter NOAA APT images [2]. This method suffers from a standard error of 6$19 \%$ for daily measurement.

Deneke et al. applied a physical retrieval method from NOAA-14 satellite data for estimation of irradiation over Netherlands [8]. It was observed that for individual assessment of 30 stations rms error was $86 \mathrm{Wm}^{-2}$ and this error was reduced to $33 \mathrm{Wm}^{-2}$ when all the stations were averaged.

\section{Conclusion}

A simple statistical method for retrieval of downwelling solar radiation from a polar orbiter satellite data has been presented. The accuracy of the method has been tested in two different approaches. The results thus obtained have been compared with other methods. It is found that the model output has reasonably good agreement with the measured values.

1. Noia, M., Ratto, C.F. and Festa, R., 1993. Solar radiation estimatiion from geostationary satellite data-I and II. Solar Energy, 51, pp. 449-465.

2. Islam, M.R. and Exell, R.H.B 1996. Solar radiation mapping from satellite image using a low cost system. Solar Energy, 56(3), 225-237.
3. Laine, V., Venalainen, V., Heikinheimo, M. and Hyvarinen, O., 1999. Estimation of Surface Solar global radiation from NOAA AVHRR data in high latitudes. J. Appl. Meteorol. $38,1706-1719$.

4. Tarpley, J. D., 1979. Estimating incident solar radiation at the surface from geostationary satellite data. J. Appl. Meteorol., $18,1172-1181$.

5. Ali, Md Shahjahan, 2011. Estimation of solar radiation on the surface of Bangladesh using satellite data. PhD Thesis, Department of Applied Physics, Electronics and Communication Engineering, Dhaka University, Bangladesh.

6. Ali, M.S., H. Rahman and R.K. Mazumder, 2008. Estimation of solar radiation from satellite images for a tropical enviromment. International Journal of Applied Environmental Sciences, Vol.3, No.3, 281-289.

7. Cano, D., Monget, J.M., Albuisson, M., Guillard, H., Regas, N. and Wald, L., 1986. A method for the determination of global solar radiation from meteorological satellite data. Solar Energy, 37, 31-39.

8. Deneke, H. A., Feijt, A., van Lammeren and Simmer, C., 2005. Validation of a physical retrieval scheme of solar surface irradiances from narrow-band satellite radiances. J. Appl. Meteorol. 44, 1453-1466. 